JAN STRADOMSKI

Instytut Filologii Słowiańskiej

Uniwersytet Jagielloński

\title{
KRZYŻ JAKO SYMBOL WŁADZY KOSMICZNEJ W BIZANTYŃSKO-SŁOWIAŃSKIEJ TRADYCJI LITERACKIEJ
}

Słowa kluczowe: hagiografia, apokryfy eschatologiczne, literatura cerkiewnosłowiańska, rękopisy cyrylickie, semiotyka

Keywords: hagiography, eschatology apocrypha, Church-Slavonic literature, Cyrillic manuscripts, semiotics

Niezbyt obszerny tekst cerkiewnosłowiańskiego prologu na dzień 21 maja, czyli dzień liturgicznego wspomnienia cesarza Konstantyna Wielkiego i jego matki Heleny, wraca do wydarzeń, jakie rzekomo miały miejsce 28 października 312 roku przy Moście Mulwijskim, godzinę drogi od północnych bram Rzymu. Jak czytamy w tekście, Konstantyn, decydując się na zbrojną rozprawę z Maksencjuszem:

ruszył z Bożą pomocą na niego, wezwawszy wsparcia Chrystusowego, albowiem Bóg widząc czystość duszy jego, wprzód we śnie mu się objawił, a w dniu następnym, w samo południe, z gwiazd znak krzyża na niebie uczynił, i napis: „Konstantynie, tym znakiem zwyciężaj!”. Raz jeszcze tenże Bóg, który umiłował człowieka, pouczył tych, co są godni tego, by pokładali ufność w znaku Krzyża świętego. I [ze znaku tego] złotem [wypisanego] broń uczyniwszy, [Konstantyn] wkroczył do Rzymu i tegoż nieprawego Maksencjusza władzy pozbawił [...] i lud rzymski od jego jarzma wyzwolit ${ }^{1}$.

Powyższy tekst jest w sposób oczywisty hagiograficzną parafrazą informacji odnotowanych przez kilku antycznych historyków - od Euzebiusza z Cezarei (Historia Ecclesiastica 9.9.1-9) począwszy, poprzez Laktancjusza (De mortibus persecutorum 44.5), Filostorgiusza (Historia Ecclesiastica 1.6), Sokratesa

\footnotetext{
${ }^{1}$ Георги Петков et Мария Спасова, ed. Търновската редакиия на Стишния пролог. Текстове. Лексикален индекс, т. IX, месец май (Пловдив: Университетско издателство „Паисий Хилендарский”, 2013), 54-55 (tłum. moje J.S.). Podobna relacja w synaksarionie na święto Podwyższenia Krzyża Świętego (14 IX). Vide: ibidem, т. I, месец септември (Пловдив: 2008), 61-62.
} 
Scholastyka (Historia Ecclesiastica 1.2), aż po Sozomena (Historia Ecclesiastica 1.3). Pierwotny przekaz o tym przełomowym - jak się później okazało - dla historii Kościoła i świata wydarzeniu, uzupełniono z czasem o nowe „fakty” i wzbogacono o szczegóły, które ukazały je w stosownym dla swej rangi, aczkolwiek jawnie mitologicznym świetle ${ }^{2}$. Trudno posądzać cesarza Konstantyna o brak zrozumienia dla wartości znaków i symboli. Antyczny świat był ich przecież pełen, stąd nie dało się oddzielić nakładających się rzeczywistości gestu i znaku. Symboliczne, choć zarazem realne, było wiele z jego działań: wydanie edyktu tolerancyjnego, zwołanie pierwszego soboru powszechnego w Nicei, imponujące fundacje świątyń w Rzymie, Jerozolimie, a potem Konstantynopolu... Samo przeniesienie stolicy cesarstwa ze starego Rzymu do nowo wybudowanego miasta nad Bosforem miało swój głęboki semantyczny wydźwięk. Jawnie symboliczno-palladyczną rolę pełniły znajdujące się w nim liczne relikwie, na czele z najcenniejszymi, jakie można było sobie wyobrazić - relikwiami Krzyża Świętego, gwoździ i korony cierniowej, po które - jak zresztą czytamy w tym samym prologu (i u dziejopisów) - Konstantyn posłał swą pobożną matkę Helenę do Jeruzalem ${ }^{3}$. Każdy początek wielkiego dzieła potrzebuje swojego wyraźnego symbolu. Przejście ze świata pogaństwa do świata chrześcijaństwa naturalnie też. Symbol nie tylko obrazuje i kondensuje ważne dla takiego aktu treści,

\footnotetext{
${ }^{2}$ Relacja Euzebiusza z Cezarei jest dość powściągliwa i - można by powiedzieć - historycznie wiarygodna. Wprawdzie zerwanie mostu na Tybrze i śmierć Maksencjusza autor przypisuje boskiej mocy sprawczej, jednak nie wspomina o innych cudownych okolicznościach. Żyjący w tym samym czasie Laktancjusz informuje jedynie o śnie przed bitwą, w którym Konstantyn został pouczony, aby na tarczach swych żołnierzy umieścił boży znak niebieski (caeleste signum dei). Edykt tolerancyjny (313 r.) i otwarcie się cesarstwa na chrześcijaństwo sprawiły, że osoba i dzieło Konstantyna stały się obiektem panegirycznej oceny ze strony Kościoła. To właśnie w przypisywanym Euzebiuszowi z Cezarei, ale najpewniej napisanym przez jego ucznia, Akacjusza, Żywocie Konstantyna znajduje się najstarszy opis cudownego znaku triumfującego krzyża na niebie i napis In hoc signo vinces, jaki mu towarzyszył (Vita Constantini 1.28). Przedstawiona tak wizja doskonale odpowiadała potrzebie czasu i kontekstowi zmieniającej się rzeczywistości religijno-politycznej cesarstwa, dlatego wyparła na plan dalszy wcześniejsze relacje o śnie. Obecna jest już wyraźnie u Filostorgiusza, Sokratesa Scholastyka i Sozomena, a także późniejszej historiografii bizantyńskiej i łacińskiej. Ze źródeł bizantyńskich przenika następnie do tradycji słowiańskiej. Odnajdujemy ją na przykład w tzw. Latopisie helleńskim i rzymskim (drugiej redakcji), zabytku niezwykle istotnym dla prześledzenia relacji południowo- i wschodniosłowiańskiej historiografii (latopisarstwa) z kronikami greckimi, a także Chronografie ruskim 1512 roku i tzw. Chronografie redakcji zachodnioruskiej. Vide Олег Викторович Творогов еt Светлана Александровна Давыдова, ed. Летописеи еллинский и римский, т. 1. (Санкт-Петербург: Издательство „Дмитрий Буланин”, 1999), 278-279; PSRL, vol. 22 part 1, 263-264; vol. 22 part 2, 83-84. Aktualny stan badań wraz z wyczerpującym wykazem literatury w trzytomowej encyklopedii Costantino I. Una enciclopedia sulla figura, il mito, la critica e la funzione dell'imperatore del cosiddetto editto di Milano, 313-2013, ed. Alberto Melloni (Rome: Enciclopedia Italiana, 2013).

${ }^{3}$ Георги Петков et Мария Спасова, op. cit., 55. Relacja o tych wydarzeniach również w Latopisie helleńskim i rzymskim (op. cit., 298).
} 
ale też posiada zazwyczaj w sobie coś z transcendencji. Gwieździsty znak krzyża na tle świetlistego nieba świetnie się do tego nadawał; legł więc u początków nowego etapu w dziejach świata - historii pokojowego (przeważnie) współistnienia państwa i Kościoła, współdziałania (symfonii) władzy cesarskiej z władza duchowną.

Motyw kosmicznego krzyża obecny jest w literaturze chrześcijańskiej nie tylko w korpusie tekstów związanych z postaciami św. Konstantyna (Wielkiego) i św. Heleny. Znajdziemy go także w żywotach św. Eustachego Rzymskiego (a. Placydusa, wsp. 20 IX; krzyż jaśniejący pomiędzy rogami jelenia) czy św. Kseni z Mylasy (Euzebii, wsp. 24 I; świetlisty krzyż na niebie w pierścieniu gwiazd w samo południe, w godzinie śmierci świętej) ${ }^{4}$. Jego obecność jest szczególnie wyrazista w tekstach patrystycznych, hagiograficznych oraz homiletyczno-parenetycznych, ponieważ zazwyczaj towarzyszy mu bogata egzegetyczno-interpretacyjna obudowa 5 . Siła oddziaływania tego symbolu i jego wielopłaszczyznowe

${ }^{4}$ Spośród wielu kompilacji hagiograficznych zawierających te teksty można wskazać choćby na cieszące się znaczną renomą Żywoty świętych Daniela Tuptały (św. Dymitra Rostowskiego). Vide Даниил Туптало, Книги житий святых, кн. 1 (сентябрь - ноябрь) (Киев: Киево - Печерская Лавра, 1689), л. чңд' (k. 94 verso); кн. 2 (декабрь - февраль) (Киев: Киево - Печерская Лавра, 1695), л. ук̈а' (k. 421 verso).

${ }^{5}$ Dotyczy ona oczywiście interpretacji obrazu miedzianego węża (Lb 21, 8) jako prefiguracji ukrzyżowanego Chrystusa (J 3, 14-15). Wczesnochrześcijańscy krzewiciele Dobrej Nowiny podjęli trudne zadanie uwolnienia symbolu krzyża od utrwalonych w kulturze przełomu er konotacji haniebnej śmierci i męczeństwa. W pismach św. Pawła Apostoła (1 Kor 1,18; Ga 5,11; 6,12.14; Flp 3,18; Ef 2,16; Kol 1,18-20; Kol 2,14) krzyż, pozostający wciąż jeszcze znakiem męczeńskiej ofiary, przedstawiany jest już w świetle nauki soteriologicznej, a zatem staje się źródłem zwycięstwa i życia (wiecznego). W okresie patrystycznym pojawiają się egzegezy łączące wyraźnie treści i obrazy Starego Przymierza z Nowym. Znajdziemy tu już nie tylko prefigurację węża miedzianego, ale powiązanie symboliki krzyża z kosmogonicznym mitem z Księgi Rodzaju (Cyryl Aleksandryjski, Teodoret, Grzegorz z Nyssy, Sewerian Gawalski). Justyn Męczennik widzi ewidentną analogię drzewa życia (Rdz 2,9) i drzewa krzyża, Ignacy i Cyryl Jerozolimski dostrzegają w nim oręż Chrystusa oraz emanację Jego mocy, a Efrem Syryjczyk i Jan Złotousty nadają krzyżowi moc egzorcyzmu. Choć jeszcze w epoce konstantyńskiej symbol krzyża nie jest podstawowym znakiem chrześcijaństwa, to jednak coraz wyraźniej zaczyna być obecny w obrzędzie i w sztuce. Dostrzegalna analogia kształtu oranty/oranta, znana już z wczesnochrześcijańskiej sztuki katakumbowej, z rozpostartym na krzyżu Chrystusem, otwiera nowe płaszczyzny semantyczne i pozwala iść w kierunku interpretacji kosmicznej i eklezjalnej (Grzegorz z Nyssy, Augustyn), a wreszcie eschatologicznej (trwający na modlitwie Kościół - mistyczne ciało Chrystusa, oczekujący paruzji, Jego powtórnego przyjścia). Utrwalającej się w przekazie kulturowym (nowej) symbolice krzyża nie zaszkodziła nawet wrogość monofizytów i ikonoklastów, a umocowanie problemu w wypowiedziach soborowych (Sobór Piąto-Szósty, In Trullo, kanon 73; Nicea II, orzeczenie 19) nadało nauczaniu status jedynej obowiązującej, oficjalnej wykładni. Kolejnym krokiem było wprowadzenie Krzyża do kalendarza liturgicznego Kościoła w szeregu świąt, zarówno w charakterze podmiotu uroczystości, jak i jej głównego artefaktu (Podwyższenie Krzyża Świętego 14 IX, Wspomnienie świętego drzewa Krzyża Pańskiego, 1 VIII; Niedziela adoracji Krzyża Świętego - Krestopokłonnaja, 3 niedz. Wielkiego Postu; każdy dzień Wielkiego Tygodnia oraz każdy piątek roku). 
biblijno-mitologiczne konotacje sprawiły, że stał się również jednym z ulubionych motywów chrześcijańskiej literatury apokryficznej, szczególnie w jej dziale apokaliptycznym i eschatologicznym ${ }^{6}$.

Objawienie Pseudo-Metodego Patarskiego ${ }^{7}$ jest klasycznym przykładem wykorzystania motywu krzyża jako symbolu władzy kosmicznej do zobrazowania scenariusza oczekiwanej przez chrześcijan apokalipsy i paruzji. Apokryf jest pod tym względem szczególnie interesujący w tzw. interpolowanym wariancie, który nie tylko jest znacznie obszerniejszy od redakcji podstawowej, ale też dodatkowy materiał narracyjny, jaki się w nim znajduje, świadczy o żywej koegzystencji dzieła $\mathrm{z}$ innymi pismami tego typu, a przede wszystkim o aktualności problematyki, która niewątpliwie stanowiła główny impuls obrastania pierwotnego testu w coraz to nowe wątki i detale ${ }^{8}$.

${ }^{6}$ Postać cesarza Konstantyna i jego matki Heleny jest również silnie obecna w folklorze Słowian prawosławnych, zwłaszcza na Bałkanach, a także stanowi historyczno-symboliczną podbudowę dla polityczno-ideologicznego programu władców ruskich (moskiewskich). Vide Мария Плюханова, Сюжеты и символы Московского иарства (Санкт-Петербург: „Акропол”, 1995), 105-124.

${ }^{7}$ Jest to jeden $\mathrm{z}$ bardziej popularnych eschatologicznych tekstów profetycznych w literaturze prawosławnych Słowian w średniowieczu, choć wydaje się, że w nie mniejszym stopniu oddziaływał na wyobrażenia o czasach ostatecznych także w kręgu kultury łacińskiej. Przypisany pseudopigraficznie Metodemu, biskupowi Patary w Licji (III-IV w.) tekst podstawowy powstał najpewniej w syryjskojęzycznym środowisku wschodnich rubieży Cesarstwa Bizantyńskiego po najazdach Arabów w VII w. Na początku VIII w. powstaje przekład grecki, a wkrótce po nim łaciński, dzięki czemu utwór staje się znany na obu wielkich europejskich obszarach wczesnośredniowiecznej kultury. Dziś przyjmuje się, że Objawienie Pseudo-Metodego Patarskiego było trzykrotnie przekładane na język słowiański (X-XI - dwukrotnie! oraz XIII/XIV) - wszystkie tłumaczenia wykonano w Bułgarii. Tekst bardzo wcześnie dociera na Ruś (XI/XII w.), gdzie też najprawdopodobniej powstała jego późniejsza, interpolowana (rozszerzona) redakcja. W epoce druku dzieło po raz pierwszy ukazało się w Kolonii ok. 1475 r. i w Augsburgu w 1496 r. (wraz z komentarzem), natomiast pierwszy polski przekład wykonany przez Mikołaja Heya Stawickiego wyszedł najpewniej w Krakowie między 1562 a 1580 rokiem. W następnych wiekach dzieło nadal było przedrukowywane i w niczym nie straciło na autorytecie i popularności. Vide Jerzy Kroczak, ed., Proroctwo Pseudo-Metodiusza z Wykładem Wolfganga Aytingera przetożyt Michat Hey Stawicki (Wrocław: Oficyna Wydawnicza ATUT. Wrocławskie Wydawnictwo Oświatowe, 2013) (zwł. Wstęp, 5-32); Jan Stradomski, Rękopisy i teksty. Studia nad cerkiewnostowiańska kulturą literacka Wielkiego Księstwa Litewskiego i Korony Polskiej do końca $X V I$ w., Krakowsko-Wileńskie Studia Slawistyczne 10 (Kraków: Wydawnictwo „Scriptum”, 2014), 144-149. W obu pracach obszernie wskazana literatura przedmiotu.

${ }^{8}$ W zbiorach rękopisów Biblioteki Narodowej w Warszawie znajduje się wyjątkowo ciekawy kodeks cyrylicki z pocz. XVI w. o sygnaturze BOZ 92, należący do kolekcji dawnej Biblioteki Ordynacji Zamoyskiej - tej samej, z której pochodzi również słynny Kodeks Supraski (BOZ 201, pocz. XI w.). W postaci, w jakiej się rękopis dziś zachował, można go określić jako kodeks apokryficzno-eschatologiczny, bowiem składa się głównie z tekstów pozakanonicznej bizantyńsko-słowiańskiej literatury egzegetycznej, hagiograficznej i parenetyczno-formacyjnej. Praktycznie każda z kopii znajdujących się w nim utworów posiada jakąś swoją charakterystyczną i ważną z punktu widzenia tekstologii cechę. Szczególnie interesujący pod tym względem jest odpis cerkiewnosłowiańskiego przekładu Objawienia Paseudo-Metodego Patarskiego. Tekst kodeksu BOZ 92 jest, według moich ustaleń, najstarszą z zachowanych do dziś, pełną kopią tzw. interpolowanej redakcji tego utworu; 
W umiłowanej przez starożytnych Greków proporcji i symetrii, której chrześcijańską syntezę stworzyli Bizantyńczycy, a później przejęli ją od nich prawosławni Słowianie, początek i koniec, jako zjawiska skrajne, powinny być do siebie podobne, powinny odwoływać się do takich samych treści, zdarzeń, postaci czy zachowań - powinny po prostu stanowić antytezę samych siebie. Naturalnie, przedstawianie wydarzeń przeszłych, zwłaszcza ubranych w symboliczny czy alegoryczny kostium, jest znacznie łatwiejsze, niż projekcja przyszłości, zwłaszcza przyszłości tak nieodgadnionej, jak koniec świata. Z pomocą przychodzi judeochrześcijańska tradycja biblijna i okołobiblijna, z kilkoma ewangelicznymi wypowiedziami Jezusa (Mt 25, 31-46) na ten temat i oczywiście kanoniczną Apokalipsa św. Jana na czele, pozwalająca czerpać tworzywo do konstrukcji opowieści o czasach ostatecznych, z symbolicznie interpretowanej historii i logicznego wnioskowania teologicznego. Tak nakreślony, główny kierunek przekazu, silnie tkwiący w fundamencie doktryny i bogato obudowany egzegezą patrystyczną, umożliwiał w miarę precyzyjne mówienie o tym, co dopiero ma nastąpić, o wydarzeniach, których - paradoksalnie i zgodnie ze słowami Jezusa - nikt przecież nie jest w stanie ani przewidzieć, ani opisać (vide: Mt 25, 13; Łk 12, 40).

Trzy ostatnie rozdziały (VIII-XI) Objawienia Pseudo-Metodego Patarskiego ${ }^{9}$ są przykładem możliwości plastycznego i sugestywnego budowania narracji apokryficznej w oparciu o precyzyjny kod semantyczny chrześcijańskiej wizji dziejów, świadczący o jej wielopłaszczyznowych mitologiczno-biblijnych i historyczno-literackich implikacjach. Jak dowiadujemy się z tekstu, zbliżającą się paruzję i sąd Syna Człowieczego nad światem poprzedzać ma pojawienie się trzech kluczowych postaci - wszetecznej królowej, sprawiedliwego cara oraz „Syna Zatracenia”, czyli Szatana albo Antychrysta. Wszystkie stanowią czytelnie skonstruowane i łatwe do rozpoznania antytypy znanych z Księgi Rodzaju postaci - przez co mają swój udział zarówno w finale, jak i początku dziejów świata.

\footnotetext{
z pewnością nie jest młodszy od wskazywanej tradycyjnie przez literaturę przedmiotu kopii z rękopisu Nr 769 biblioteki Lawry Troice-Sergiejewskiej (pocz. XVI w.), która jednak jest zdefektowana i nie posiada zakończenia. Odpis warszawski jest nie tylko kompletny, ale zachowuje też nieobecne w innych rękopisach frazy oraz bardziej archaiczne formy języka, pozwalające łączyć go z najstarszymi południowosłowiańskimi przekładami tego apokryfu, jakie wykonano w Bułgarii w X-XI w. Zresztą na bazie tychże południowosłowiańskich przekładów sporządzono tzw. interpolowaną redakcję tekstu, najprawdopodobniej na Rusi około XV w., choć nie wykluczone też, że na Bałkanach i to znacznie wcześniej. Szerzej na temat tradycji historyczno-literackiej Objawienia Pseudo-Metodego Patarskiego, a także opis kodeksu BOZ 92 i uwagi na temat warszawskiej kopii apokryfu, vide Jan Stradomski, op. cit., 113-192 (zwł. 144-160).

${ }^{9}$ Posługuję się tekstem warszawskiego rękopisu BOZ 92 (s. 231-259). Najpełniejsze wciąż i nadal cytowane wydanie trzech podstawowych wariantów utworu Wasilija Michajłowicza Istrina, idem, Откровение Мефодия Патарского и апокрифические видения Даниила в византийской и славяно-русской литературах. Исследование и тексты (Москва: Университетская типография, 1897).
} 
Po szeregu znaków i wydarzeń, mających zwiastować czasy ostateczne, na wschodzie pojawić się ma władczyni z Pontu o imieniu Mandona (Mandana, Maona), która panować będzie w Aleksandrii. Postać Mandony, „córki diabelskiej”, jest w swej budowie literackiej dość przewidywalna i w zasadzie stanowi ucieleśnienie obrazu biblijnej „nierządnicy Babilońskiej”. Jej panowanie charakteryzować się będzie gwałtami, grabieżami i morderstwami, niezwykłą rozwiązłością seksualną i obyczajową, profanacją miejsc świętych oraz prześladowaniem sprawiedliwych. Królowa będzie sprawczynią totalnej destrukcji istniejących w świecie praw boskich i praw naturalnych oraz wszelkich akceptowalnych relacji międzyludzkich. W rzeczy samej Mondona - choć w apokryfie nie znajdziemy wprost tej informacji - jest antytezą upadłej Ewy: skrajna pycha pozwala jej uznać się za równą Bogu, otwarcie wystąpić przeciwko Stwórcy i prowokacyjnie rzucić Mu wyzwanie. Jak pramatka Ewa sprowadziła grzech, czas fizyczny, śmierć i cierpienie na rodzaj ludzki, tak też Mondona za swe bluźnierstwo i bunt przeciwko Bogu ściąga na ziemię apokaliptyczną katastrofę ${ }^{10}$. Bóg pośle więc archanioła Michała, aby zniszczył miasto nieprawości wraz z jego mieszkańcami. Ten spektakularny akt mocy Bożej i obraz klęski buntowniczki powiązany jest jednak ze znakiem tryumfu i ocalenia. W apokryficznej narracji stolice w całości pochłaniają morskie fale, ale na centralnym placu miasta pozostaje wystająca z morskiej otchłani kolumna, na szczycie której znajdą ocalenie gwoździe z krzyża Chrystusowego. Relikwie gwoździ, jak dowiadujemy się z tekstu, nakazał umieścić w złotej figurze (bałwanie lub skrzynce) nie kto inny, jak cesarz Konstantyn (Wielki), aby w miejscu tym czekały na powtórne przyjście Syna Człowieczego (jako dowód „winy” i „wstydu” dla Żydów). Stercząca niczym oś ziemi (axis mundi) kolumna, ma służyć do cumowania przybywającym tu statkom dawnych mieszkańców Aleksandrii, którzy znajdując przy niej ocalenie, będą przez 40 dni lamentować nad upadkiem miasta ${ }^{11}$. Alegoryczna figura apokaliptycznej katastrofy miasta stołecznego i sterczącej z morskiej kipieli kolumny niewątpliwie odnosi się do Konstantynopola. Świadczy o tym wspomniany obelisk w centrum miasta, która natychmiast przywodzi na myśl stojącą pośrodku wielkiego forum Konstantyna Wielkiego porfirową kolumnę,

${ }^{10} \mathrm{~W}$ odróżnieniu od Ewy, Mandona nie żałuje za swe uczynki i nie podejmuje pokuty. Motyw pokuty Ewy rozwijają niektóre bizantyńskie i słowiańskie apokryfy, z których najpopularniejszym i najbardziej rozpowszechnionym we wschodniosłowiańskiej tradycji rękopiśmiennej jest Słowo o Adamie $i$ Ewie. Polski przekład z komentarzem vide Georgi Minczew et Małgorzata Skowronek, ed., Apokryfy i legendy starotestamentowe Stowian Południowych (Kraków: Wydawnictwo Uniwersytetu Jagiellońskiego, 2006), 30-44.

${ }^{11}$ Analogiczny opis zagłady miasta, pochłoniętego przez morze, w którym jest mowa już wprost o Konstantynopolu, znajduje się w pochodzącym w podobnego okresu i wykazującym wiele tekstologicznych zależności od Objawienia Pseudo-Metodego - Żywocie Andrzeja Jurodiwego, którego obszerny fragment - notabene - znajduje się w tym samym warszawskim kodeksie BOZ 92 (411-452). 
na szczycie której rzeczywiście, jak podają historycy, znajdował się pozłacany posąg, wyobrażający najprawdopodobniej postać Sol Invictus w osobie cesarza Konstantyna, z koroną na głowie ozdobioną siedmioma promieniami słonecznymi. W nich to z czasem lud Konstantynopola zaczął dopatrywać się gwoździ Męki Pańskiej, skoro powszechnie wiadomym było, że na szczycie kolumny znajdują się też relikwie drzewa Krzyża Świętego ${ }^{12}$.

Jedynym ważniejszym od stolicy cesarstwa i bardziej od niej świętym dla Bizantyńczyków i Słowian miastem mogła być tylko Jerozolima, tak więc tam mają się rozegrać ostatnie akty dramatu doczesnej historii. Antytyp Adama, pierwszego człowieka i władcy, któremu Bóg w czasach rajskich powierzył panowanie nad ziemią ${ }^{13}$, stanowi w Objawieniu Pseudo-Metodego Patarskiego osoba ostatniego ziemskiego króla - Michała ${ }^{14}$. To za jego panowania właśnie ma się objawić Antychryst - antyteza Chrystusa, który podobnie jak On (Chrystus) przyjdzie na świat w niezwyczajnych okolicznościach, i zanim objawi się światu i rozpocznie swą publiczną działalność, będzie wychowywał się na uboczu. Analogii i aluzji biblijnych w tym fragmencie apokryfu jest bez liku (co zresztą potwierdzają liczne cytaty i parafrazy). Osoba Antychrysta związana będzie z trzema miastami w Ziemi Świętej: narodzi się w Charazinie (lub Zin), wychowa się w Betsaidzie, a władał będzie w Kafarnaum (to znów osadzone w cytacie biblijnym, por. Mt 11, 21-23).

$\mathrm{Z}$ literackiego punktu widzenia, niezwykle ciekawy jest sam opis poczęcia Antychrysta. Jak czytamy w tekście, pewna mniszka (oczywiście dziewica) w mieście Charizin, siedząc w swej klasztornej celi, ma usłyszeć dobiegający z winnicy śpiew ptaka tak przecudny, ,jakiego żaden człowiek nie słyszał”. Gdy zechce zobaczyć skąd ten śpiew dochodzi, uchyli okiennicę, a wtedy ptak uderzy ją (skrzydłem) w twarz, i wówczas pocznie w swym łonie „syna zatracenia”.

${ }^{12}$ Sławomir Bralewski, „Porfirowa kolumna w Konstantynopolu i jej wczesnobizantyńska legenda”, Vox Patrum 30 (2010), t. 55, 99. Bez wątpienia w jakimś związku z przekonaniem tym pozostaje tekst synaksarionu na dzień 11 maja, w którym czytamy: „i wkroczył na forum, gdzie mieszkańcy miasta postawili posąg jego [tj. Konstantyna - J.S.], z głową zwieńczoną gwoźdźmi Chrystusa i Boga naszego. Tam też, pod ziemią [w sanktuarium - J.S.], leży dwanaście koszy ułomków chleba, które pozostały [z cudownego rozmnożenia przez Jezusa - J.S.]”. Георги Петков еt Мария Спасова, op. cit., т. IX, 33. Należy przypuszczać, że wspomniana tu figura Konstantyna posiadała hełm lub koronę z relikwiami gwoździ z Krzyża. Ten sam motyw pojawia się w greckich synaksarionach na dzień 14 września.

${ }^{13}$ Kolejny wątek apokryficzny, silnie akcentowany w pismach takich jak Grota Skarbów, O Morzu Tyberiadzkim, Stowo o Adamie i Ewie, in Antoni Tronina et Marek Starowieyski, ed., Apokryfy syryjskie (Kraków: Wydawnictwo WAM, 2011), 106-114; Apokryfy i legendy..., 3-11, 30-44.

${ }^{14}$ Motyw Michała, jako ostatniego apokaliptycznego władcy chrześcijańskiego, pojawia się w wielu tekstach bizantyńskiej i słowiańskiej apokryfiki, będących w trudnych do precyzyjnego określenia relacjach tekstologicznych z Objawieniem Pseudo-Metodego Patarskiego. Zależności te są widoczne zwłaszcza w słowiańskich przekładach Wizji proroka Daniela, Pouczenia (egzegezy) proroka Daniela, Powieści o proroku Izajaszu czy Wizji proroka Izajasza o czasach ostatecznych. 
Ewangelicznych analogii tego fragmentu chyba nie trzeba przywoływać. Gdy Antychryst osiagnie wiek dojrzały, będzie umiłowanym sługą ostatniego cara Michała i początkowo w niczym nie objawi pragnienia władzy nad światem. Sprawiedliwy car Michał nie rozpozna też kim jest Antychryst. Dopiero w dwunastym roku panowania Michała Antychryst ujawni swoje szatańskie królestwo. Początek jego panowania na ziemi, jak wiadomo z kanonicznej Apokalipsy św. Jana (Ap 13, 1-8), ma być ostatnim sygnałem zbliżającej się paruzji. W takiej sytuacji powinny nastąpić wydarzenia, spinające w całość wielką boską historię - koniec powinien być powiązany z początkiem, zarówno symbolicznie, jak i w sposób rzeczywisty. Fabuła apokryficzna konsekwentnie realizuje ten scenariusz. Michał, z natchnienia Bożego, uda się na wzgórze Golgoty, gdzie symbolicznie odda Bogu władzę nad światem. Na słonecznym niebie wówczas ukaże się świetlisty Krzyż, który obniży się i zatrzyma na chwilę przed Michałem, a ten zdejmie z głowy swą koronę i w obecności całego ludu jerozolimskiego, włoży ją na Krzyż. Wyciągnąwszy ręce w stronę nieba, Michał przekaże tym gestem ziemskie panowanie i władzę Bogu, po czym odda ducha i zaśnie snem wiecznym. W tym czasie Krzyż wraz z koroną uniesie się na powrót do nieba, a lud, widząc umarłego władcę, zrozumie, że oto rozpoczyna się ostatni dzień istnienia tego świata i zacznie lamentować ${ }^{15}$.

Zarówno wybór miejsca, jak i dobór wydarzeń nie są tu oczywiście przypadkowe. Oddanie władzy nad światem ma się dokonać w miejscu, gdzie ta władza została człowiekowi powierzona, gdzie zgodnie z tradycją judeo-chrześcijańską, kiedyś znajdował się raj, gdzie jest grób praojca Adama i jego czaszka, na tym samym wzgórzu, gdzie Drugi Adam - Chrystus, został rozpięty na krzyżu i zawieszony między niebem i ziemią ${ }^{16}$. Przecinające się horyzontalnie i wertykalnie belki krzyża łączą podstawowe kierunki ludzkiej orientacji przestrzennej - górę z dołem i prawą stronę z lewą, i jako takie stanowią starożytny symbol kosmiczny wędrującego słońca. Męczeńska śmierć Jezusa z Nazaretu, która dla chrześcijan stanowi centrum myśli soteriologicznej, pozwoliła - jak wspomnieliśmy - uwolnić ten symbol od negatywnych konotacji krzyża jako atrybutu haniebnej śmierci niewolników i buntowników, zaś myśl patrystyczna wyraźnie

${ }^{15}$ Przedstawiona tu narracja pochodzi $\mathrm{z}$ najpełniejszej, tzw. interpolowanej redakcji tego apokryfu. W pierwotnym przekładzie, jaki wykonany został w X-XI w. w Bułgarii jest mowa po prostu o greckim carze, który będzie panował w Jeruzalem, a Antychryst zrodzi się w ziemi Zin. Nie ma też wspomnianej królowej Mandony, ani okoliczności w jakich poczęty zostanie Antychryst. Opis nie należy więc do pierwotnej, bizantyńskiej redakcji tekstu, która znana była w kulturze zachodniej Europy w przekładzie na język łaciński (a później też staropolski).

${ }^{16}$ Lokalizację grobu Adama wskazują pisma apokryficzne komentujące pochodzenie krzyży z Golgoty (Opowieść o Drzewie Krzyżowym, Stowo św. Grzegorza Teologa o Świętym Krzyżu i o dwóch totrach vide Apokryfy i legendy..., 61-189), które - jako część tradycji Kościoła - stały się zapewne inspiracją dla niektórych homiletycznych i egzegetycznych wypowiedzi patrystycznych (lub odwrotnie), a także ikonografii wschodnio-chrześcijańskiej (zwłaszcza sceny Ukrzyżowania). 
go połączyła z biblijnym mitem kosmogonicznym i obrazem axis mundi. Rajskie drzewo poznania dobra $i$ zła, przez które pojawił się grzech w świecie, staje się figurą krzyża na Golgocie, przez który ten grzech został zgładzony. Symbol zwycięstwa diabła (Satanaela) kontra symbol zwycięstwa Syna Bożego (Emmanuela). Wyposażony w tak pojemną platformę semantyczną krzyż stał się czytelnym atrybutem władzy, zarówno $\mathrm{w}$ aspekcie ziemskim (kościelnym i świeckim), jak i kosmicznym. We właściwej dla późnoantycznej i średniowiecznej percepcji dwupłaszczyznowości obrazowania, materialny i fizyczny - choć niezaprzeczalnie cudowny! - krzyż Chrystusa, jaki odnalazła św. Helena, ma też (bo musi mieć!) swój transcendentny, niebieski ekwiwalent, który niezależnie od losów ziemskiej relikwii, jest uniwersalnym znakiem władzy Boga (Pantokratora) nad światem. Jako taki może ukazywać się (i ukazuje) w jakimkolwiek czasie i w jakimkolwiek miejscu, zazwyczaj w jakimś szczególnie istotnym momencie historii. Każdorazowo stanowi oczywisty znak obecności Boga i swoiste memento, które nie pozwala zapomnieć, że nad/ponad tym światem jest jeszcze in n a w $ł$ a d z a - jeszcze bardziej realna (prawdziwa) i jeszcze bardziej potężna - r e aln e pan ow anie.

Człowiek może sprawować władzę nad światem doczesnym jedynie dlatego, że została mu ona dana (por. Rdz 1, 28-29; J 19,11), albowiem źródło władzy jest tylko jedno i ma ono swoje bezpośrednie umocowanie w boskim namiestnictwie. Czy ludzie tamtych czasów to rozumieli? Gdy w 476 r. Odoaker zdetronizował ostatniego cesarza zachodniorzymskiego Romulusa Augustulusa, zajął oczywiście podległe mu niegdyś ziemie i splądrował jego stolicę, zgarniając prawem zdobywcy znajdujące się w niej kosztowności. Ale w cztery lata później (480 r.) odesłał na Wschód - cesarzowi Zenonowi, insygnia władzy cesarskiej, których nie ośmielił się zatrzymać. Ten barbarzyńca rozumiał, że przynależą one „prawowitemu" władcy cesarstwa, które na Zachodzie wprawdzie przestało istnieć w sferze politycznej lub empirycznej, ale nie w sferze idei. Odoaker wiedział, że znaczenie regaliów jako symbolu władzy cesarskiej „przekracza realność i należy do sfery powinności" ${ }^{17}$. Z tego samego powodu kazał bić monety nie $\mathrm{z}$ własna podobizną, ale $\mathrm{z}$ wizerunkami cesarzy wschodniorzymskich. Podobnie zresztą uczynił też król Ostrogotów Witigis, który rywalizując z cesarzem Justynianem o kontrolę nad Italią, też kazał wybijać na monetach podobiznę Justyniana, gdyż rzeczywista władza, władza cesarska, należała niepodzielnie do tego ostatniego ${ }^{18}$. Pamiętając o tym zrozumiemy, dlaczego koronacja Karola Wielkiego w Boże Narodzenie 800 r. była tak wielkim szokiem dla Bizantyńczyków i długo uznawana była na Wschodzie za zwykłą uzurpację.

${ }^{17}$ Sergiusz Awierincew, „Symbolika wczesnego średniowiecza”, trans. Andrzej Szymański, Literatura na Świecie, no. 12 (1980): 36.

${ }^{18}$ Ibidem. 
Obraz widniejącego na firmamencie nieba świetlistego krzyża jest dla cywilizacji chrześcijan niewątpliwie znakiem prawdziwej władzy i panowania, gdyż odwołuje się do rzeczywistości - transcendentnej i wiecznej, a zatem jedynej pewnej. Tak jak towarzyszył pierwszemu cesarzowi, który uznał religię Jezusa z Nazaretu za prawdziwą (niezależnie od rzeczywistych motywacji, którymi kierował się Konstantyn), tak też towarzyszyć będzie (bo powinien towarzyszyć) ostatniemu władcy ziemskiemu, kiedy to historia i czas fizyczny będą dobiegać swego kresu. Lecz czy znaku tego spodziewać się należy jedynie w czasach ostatecznych? Naturalnie, że nie. Stowo pochwalne ku czci Konstantyna $i$ Heleny patr. Eutymiusza Tyrnowskiego (XIV w.) wspomina nie o jednym, ale trzech objawieniach Krzyża, jakich doświadczył Konstantyn - przed bitwą z Maksencjuszem, przed zajęciem miasta Byzantion, oraz przy budowie kamiennego mostu na Dunaju w czasie wyprawy przeciwko Scytom ${ }^{19}$. Tradycja liturgiczna Kościoła Wschodniego rokrocznie wspomina cud, jaki miał miejsce 7 maja $351 \mathrm{r}$. w Jerozolimie, gdy w dniu Pięćdziesiątnicy o trzeciej godzinie dnia (czyli po 9.00 rano) ukazał się nad Golgotą krzyż jaśniejszy od słońca, którego ramiona sięgały aż po Górę Oliwną ${ }^{20}$. Taki sam krzyż, sięgający od ziemi do nieba, zobaczy później wędrujący po raju staroruski mnich Agapiusz ${ }^{21}$. Przykładów zapewne można by wskazać tu więcej.

W średniowiecznym grecko-słowiańskim systemie obrazowania przeplatają się dwie rzeczywistości, z których tylko jedna, transcendentna, istnieje tak naprawdę, gdyż jest wieczna. To w niej znajduje się stemma Pantokratora - znak jedynego i rzeczywistego panowania - znak, który niekiedy tylko jest dane ujrzeć człowiekowi. Te hierofanie zawsze jednak są po stronie Boga, mają swoje uzasadnienie i swój konkretny cel. Bowiem za każdym razem, gdy na firmamencie nieba ukazuje się świetlisty krzyż, jest on kosmicznym symbolem władzy absolutnej.

${ }^{19}$ Vide Werke des Patriarchen von Bulgarien Euthymius (1375-1393). Nach den besten Handschriften herausgegeben von Emil Katužniacki (Wien: In Commission bei Carl Gerold's Sohn, 1901), 27-58; nowe wydanie z uzupełnieniami Dymitra Kenanowa (Wielkie Tyrnowo: Издателство ПИК. Университетско издателство „Св. св. Кирил и Методий”, 2010), 162, 166, 167.

${ }^{20}$ Георги Петков et Мария Спасова, op. cit., 21-22. To kolejne, oprócz wymienionych wyżej (p. 5), święto (Знамение Kреста - Święto Znaku Krzyża) prawosławnego kalendarza liturgicznego, w centrum którego stoi Krzyż. Grecka i słowiańska cerkiew obchodzą je dniu 7 maja, natomiast ormiańska wiąże wspomnienie z cyklem triodnym ( 28 dzień po Passze), dlatego święto jest ruchome i może przypadać w okresie od 19 kwietnia do 23 maja. Podstawowym źródłem informacji o tym wydarzeniu jest relacja naocznego świadka, św. Cyryla Jerozolimskiego (Epistula ad Constantinum imperatorem, PG 33, coll.1165-1175), ale wspominają o nim również inni historycy i pisarze starożytności tacy jak Sozomenos (Ecclesiastica Historia 4.5) czy Aleksander Mnich (De inventione vivisicae crucis, PG 87, coll. 4069). Inne źródła vide PG 33, coll. 1175-1178.

${ }^{21}$ „Сказание отца нашего Агапия”, trans. et ed. Милена Всеволодовна Рождественская, in Памятники литературы Древней Руси. ХІІ век, ed. Лев Александрович Дмитриев еt Дмитрий Сергеевич Лихачев (Москва, 1980), 161. 


\section{CROSS AS THE SYMBOL OF COSMIC POWER IN THE BYZANTINE AND SLAVIC LITERARY TRADITION}

\section{Sum mary}

The image of a cross appearing in the sky has been present in Christian literature not only in the body of texts related to several saints, but it has also become one of the most favourite motives of Christian apocryphal literature, especially in its apocalyptic and eschatological section. Revelation of Pseudo-Methodius Patarensis, which is very popular in Medieval literature, is an example of using the motive of a cross as a symbol of cosmic power to illustrate the scenario of the apocalypse and the second advent awaited by Christians. In the apocryphal text, the image of the cosmic cross serves, inter alia, the purpose of graphic and suggestive presentation of the fundamental axiom of that period concerning the existence and co-dependence of two intermingling parallel worlds, namely the earthly (material, mundane) and the heavenly one (divine, eternal). The text constitutes an example of building apocryphal narrative on the basis of a precise semantic code of the Christian vision of times (the past and also the future) testifying to its multi-faceted mythological, biblical, historical and literary implications.

S k ró ty:

PG - Patrologiae cursus completus. Series Graeca, acc. J.-P. Minge, t. 33, Paris 1857; t. 87, Paris 1865.

PSRL - Полное собрание русских летописей, т. 22, Русский хронограф. Часть 1. Хронограф редакиии 1512 года. С-Петербург: Типография М.А. Александрова, 1911; Полное собрание русских летописей, т. 22, Русский хронограф. Часть 2. Хронограф ЗападноРусской редакиии, Петроград: Типография М.А. Александрова, 1914. 